\title{
STUDI HIDROLOGI BERDASARKAN CLIMATE CHANGES MENGGUNAKAN MODEL SWAT DI DAERAH TANGKAPAN AIR WADUK JATILUHUR
}

\author{
Budi Darmawan Supatmanto" Sri Malahayati Yusuf ${ }^{2)}$ \\ ${ }^{1}$ UPT Hujan Buatan - BPPT, Jalan MH Thamrin no 8, Jakarta Pusat \\ ${ }^{2}$ IImu Pengelolaan DAS IPB, PPLH IPB
}

\begin{abstract}
Intisari
Daerah Tangkapan waduk Jatiluhur berada diantara 107011'36" - 107032'36" BT and 6029'50" $6^{\circ} 40^{\prime} 45^{\prime \prime}$ LS di Jawa Barat, Indonesia. Area dengan luas $380 \mathrm{~km}^{2}$ merupakan $8 \%$ dari seluruh total area Hulu Sungai Citarum seluas $4500 \mathrm{~km}^{2}$. Fungsi dari daerah ini untuk memenuhi kebutuhan air untuk pertanian di Karawang dan Bekasi dan memenuhi kebutuhan air di Jakarta. Tujuan dari penelitian ini untuk meneliti dampak dari perubahan ik (Climate Changes) terhadap hasil hidrologi di daerah tangkapan. Perubahan iklim ditentukan oleh beberapa scenario perubahan iklim yang disiapkan sebagai input dalam SWAT hidrologi model. Simulasi dilakukan sesudah model dikalibrasi untuk mendapatkan parameter model yang sesuai dengan model hidrologi. Setelah itu model divalidasi untuk mengetahui bahwa model menggambarkan keadaan lapangan. hasil penelitian menunjukkan bahwa nilai-nilai limpasan dan hasil air yang bervariasi berdasarkan perubahan iklim. Oleh karena itu, perlu adanya untuk mempertimbangkan faktor-faktor perubahan iklim untuk mempelajari proses hidrologi di Daerah Tangkapan Air.
\end{abstract}

Kata Kunci: SWAT, hidrologi, skenario perubahan iklim dan area tangkapan

\begin{abstract}
Jatiluhur Reservoir Catchment Area is located between 107 $11^{\prime} 36^{\prime \prime}$ - 107 $32^{\prime} 36^{\prime \prime}$ BT and 6 $29^{\prime} 50^{\prime \prime}$ $6^{\circ} 40^{\prime} 45^{\prime \prime} L S$ in West Java, Indonesia. The catchment area embraces $380 \mathrm{~km}^{2}$, which is $8 \%$ of the total coverage area in the upstream of Citarum River with the total area of $4500 \mathrm{~km}^{2}$. The functions of this catchment are essential for meeting the needs of water for agriculture in Karawang and Bekasi area, and drinking water needs for Jakarta area. The purpose of this study was to investigate the impact of climate change on hydrology yield in the catchment. Changes in climate are discovered by several different climate changes scenarios, prepared as input for hydrological model SWAT. Simulation scenarios conducted after the model is calibrated in order to obtain model parameters that are sensitive to the hydrological response. Afterwards models are validated to find out that the model has described the state of the field. The result showed that the values of runoff and water yield are varies based on climate change. Therefore, there is a need to consider the factors of climate change in order to study hydrological process of a watershed.
\end{abstract}

Keywords: SWAT, hydrology, climate changes scenarios and catchment areas.

\section{PENDAHULUAN}

Daerah Aliran Sungai (DAS) merupakan suatu daerah yang di dalamnya terdapat interaksi berbagai faktor baik fisik, biologi, sosial-ekonomi maupun lingkungan yang mempengaruhi fungsi hidrologi dan tanah yang dapat mendukung keberlanjutan suatu ekosistem (Potyondy and Geier 2011). Faktor fisik dalam suatu DAS ada yang sifatnya dapat dipengaruhi oleh manusia ataupun tidak. Adapun faktor fisik yang dapat dipengaruhi oleh manusia yang paling utama adalah penggunaan lahan, sedangkan faktor fisik yang tidak dapat dipengaruhi manusia yaitu iklim. Iklim terutama curah hujan sangat penting dipelajari karena merupakan masukan utama dalam suatu DAS yang pada akhirnya akan menjadi debit.

Perubahan iklim akan mengakibatkan terjadinya perubahan sumberdaya air. Hal ini pada akhirnya menyebabkan recharge air bawah tanah berkurang sehingga menyebabkan kekeringan pada musim kemarau. Selain itu, perubahan iklim juga menyebabkan terjadinya perubahan suhu terutama peningkatan suhu. Berdasarkan data yang dirangkum oleh IPCC (2007) diketahui bahwa telah terjadi peningkatan suhu udara global sejak tahun 1861 sebesar $0.6^{\circ} \mathrm{C}$ terutama akibat aktivitas manusia. 
Berdasarkan hasil pengamatan data selama 157 tahun menunjukkan adanya peningkatan suhu permukaan bumi sebesar $0,012^{\circ} \mathrm{C}$. Peningkatan rata-rata menjadi sebesar $0.052^{\circ} \mathrm{C}$.

Perubahan pola dan distribusi hujan juga terjadi di beberapa DAS di Indonesia, salah satunya yaitu DAS Citarum, Jawa Barat. Perubahan yang terjadi yaitu berupa peningkatan hujan sebesar 0 hingga $10 \%$ di musim hujan dan menurun sebesar 5 hingga 25\% di musim kemarau (Yuwono 2013). Fenomena tersebut akan berdampak pada meningkatnya resiko banjir dan kekeringan di wilayah DAS Citarum. Pengaruh lainnya yaitu 1) kegagalan panen yang mencapai 2 kali lipat lebih besar dibandingkan saat ini, 2) jumlah wilayah terkena banjir semakin meningkat (28 kecamatan), dan 3) kemampuan produksi listrik dari tenaga air akan mengalami penurunan yang signifikan terutama di musim kemarau. Daerah tangkapan Jatiluhur merupakan salah satu wilayah yang berada di dalam DAS Citarum yang juga mengalami dampak perubahan iklim. Oleh karena itu penelitian ini bertujuan untuk mengkaji dampak perubahan iklim terhadap hidrologi daerah tersebut.

Penelitian secara langsung di lapangan tidak mungkin dilakukan karena kompleksitas yang sangat besar, maka digunakanlah suatu model hidrologi untuk membantu kajian tersebut. Model hidrologi adalah sebuah bentuk sederhana dari sebuah sistem hidrologi yang sangat kompleks yang menggambarkan berbagai interaksi antara komponen-komponen yang terkait di dalamnya. Komponen-komponen tersebut meliputi iklim, tanah, penggunaan lahan dan pengelolaan lahan dimana proses keterkaitannya menggambarkan proses yang terjadi di dalam suatu DAS.

Model hidrologi yang digunakan yaitu model SWAT. SWAT merupakan model yang dikembangkan untuk memprediksi pengaruh pengelolaan lahan terhadap hasil air, sedimen, muatan pestisida dan kimia hasil pertanian yang masuk ke sungai atau badan air pada suatu DAS yang kompleks dengan tanah, penggunaan tanah dan pengelolaannya yang bermacammacam sepanjang waktu yang lama (Neitsch et al., 2005). Hasil penelitian Guo et al., (2004) menunjukkan bahwa SWAT juga dapat digunakan untuk mengkaji dampak perubahan iklim.

\section{ANALISIS UMUM}

Waduk Jatiluhur adalah salah satu waduk yang paling penting yang terletak di Jawa Barat, Indonesia. DAS Jatiluhur terletak antara $107^{0} 11^{\prime} 36^{\prime \prime}$ - 107 $32^{\prime} 36^{\prime \prime}$ BT dan 6029'50" $6^{0} 40^{\prime} 45^{\prime \prime}$ LS di Jawa Barat, Indonesia. Daerah tangkapan air mencakup area seluas $380 \mathrm{~km}^{2}$
(Gambar 1), yang merupakan 8\% dari cakupan area total dalam hulu sungai Citarum dengan luas total $4500 \mathrm{~km}^{2}$.

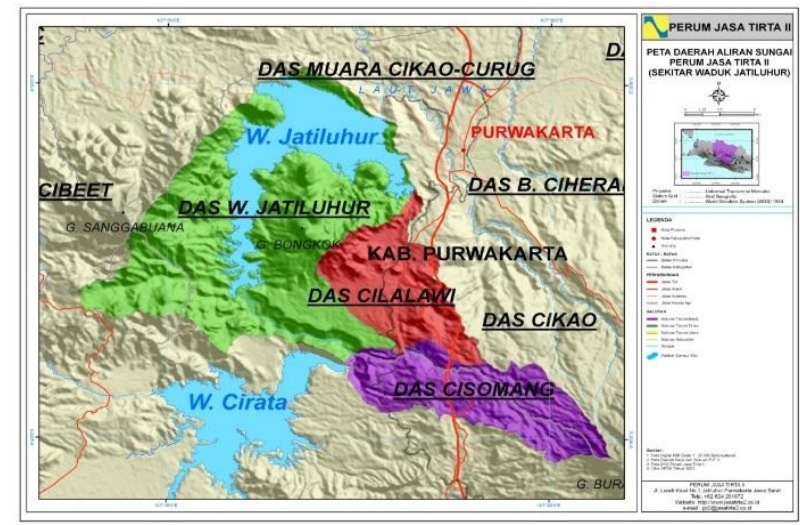

Gambar 1. DAS Waduk Jatiluhur

\section{a. Iklim}

Daerah penelitian termasuk kedalam tipe iklim D berdasarkan klasifikasi SchmidtFerguson (tingkat kebasahan sedang). Curah hujan tahunan Daerah Tangkapan Waduk Jatiluhur sangat bervariasi dengan curah hujan rata-rata sebesar $213.54 \mathrm{~mm}$, dan curah hujan tertinggi sebesar $107,76 \mathrm{~mm}$. Temperatur maksimum rata-rata $32,45^{\circ} \mathrm{C}$ dan minimum ratarata $20.72^{\circ} \mathrm{C}$. Rata-rata radiasi matahari bulanan sebesar $16,65 \mathrm{MJ} / \mathrm{m}^{2} /$ hari dan kelembaban udara sebesar 90,33\%. Berdasarkan data iklim tersebut, nilai evapotranspirasi aktual rata-rata harian selama periode simulasi Juni sampai Desember 2009 adalah sebesar $1.10 \mathrm{~mm}$ dengan kisaran antara 0-4.16 mm. Namun nilai evapotranspirasi potensial adalah sebesar $493.69 \mathrm{~mm}$.

\section{b. Penutupan Lahan DAS Jatiluhur}

Hasil analisis peta penutupan lahan (land cover) DAS Jatiluhur tahun 2009 (Gambar 1) menunjukkan bahwa DAS Jatiluhur memiliki 10 jenis penutupan lahan meliputi hutan sekunder, kebun campuran, perkebunan, permukiman, rawa, sawah, semak belukar, tanah terbuka, tegalan/ladang, dan tubuh air. Adapun jenis penutup lahan yang dominan adalah sawah $(31,16 \%)$ dan rawa $(0,06 \%)$ merupakan tutupan lahan yang paling sedikit (Tabel 1.). Jenis tutupan lahan tersebut akan mempengaruhi besarnya persentase curah hujan yang menjadi aliran permukaan. Semakin luas area yang tertutup vegetasi maka semakin banyak area yang dapat menyerap air sehingga air akan lebih banyak tersimpan di lahan. 


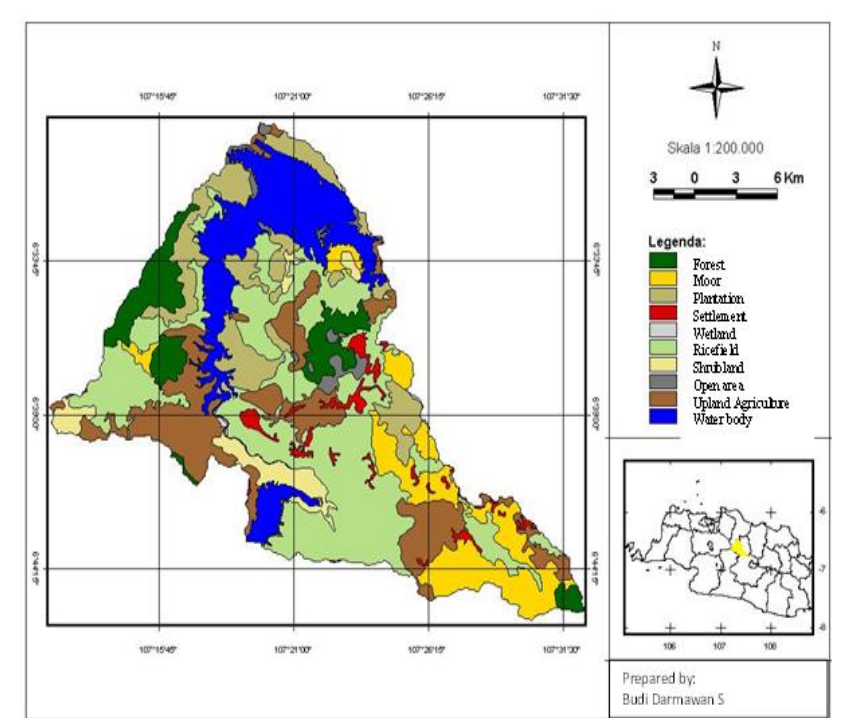

Gambar 2. Peta Land Cover DAS Jatiluhur Tahun 2009

\section{c. Peta Tanah DAS Jatiluhur}

Hasil analisis peta tanah menunjukkan bahwa di DAS Jatiluhur terdapat 7 macam tanah dengan dominasi jenis tanah latosol, kemudian diikuti oleh podzolik, grumusol dan andosol. Tanah-tanah latosol umumnya banyak mengandung zat besi dan aluminium. Tanan ini umumnya sudah sangat tua sehingga tingkat kesuburannya rendah. Warna tanahnya merah hingga kuning. Pada umumnya tanah latosol memiliki tekstur liat berdebu, liat, dan lempung berliat.

Tanah podzolik umumnya terbentuk di daerah yang memiliki curah hujan tinggi dan suhu udara rendah. Karaktersitik tanah ini yaitu tingkat kesuburan sedang, tekstur yang lempung atau berpasir, memiliki $\mathrm{pH}$ rendah, serat kandungan aluminium dan besi yang tinggi. Tanah grumusol adalah tanah yang terbentuk dari material halus berlempung dan umumnya berwarna kelabu hitam dan bersifat subur. Tanah Andosol adalah tanah yang berasal dari abu gunung api. Umumnya terdapat di lerenglereng gunung api sehingga tingkat kesuburan tanah ini tinggi.

\section{d. Topografi DAS Jatiluhur}

Topografi DAS Jatiluhur bervariasi dari datar hingga curam. Sebagian besar DAS Jatiluhur didominasi oleh topografi datar yaitu sebesar $37.88 \%$ sedangkan topografi sangat curam sebesar $7.53 \%$. Adapun kelas lereng dikelompokkan seperti disajikan pada Tabel 1. berikut :
Tabel 1. Kelas Lereng DAS Jatulihur

\begin{tabular}{|c|c|l|l|}
\hline \multirow{2}{*}{ No. } & \multirow{2}{*}{\begin{tabular}{c} 
Kelas \\
\cline { 3 - 4 }
\end{tabular}} & \multicolumn{2}{|c|}{ Lereng } \\
\cline { 3 - 4 } & ha & \% DAS \\
\hline 1 & $0-8$ & $19,084.60$ & 37.88 \\
\hline 2 & $8-15$ & $10,858.74$ & 21.55 \\
\hline 3 & $15-25$ & $11,087.87$ & 22.01 \\
\hline 4 & $25-40$ & $5,554.08$ & 11.02 \\
\hline 5 & $>40$ & 3794.6 & 7.53 \\
\hline & Total & $\mathbf{5 0 , 3 7 9 . 8 9}$ & $\mathbf{1 0 0}$ \\
\hline
\end{tabular}

\section{METODE}

Bahan-bahan yang digunakan dalam penelitian ini adalah peta tanah tinjau mendalam skala 1:100.000, peta rupa bumi skala 1:25.000, peta DEM (Digital Elevation Model), peta penutupan lahan tahun 2009 data debit aliran, data saluran sungai, data curah hujan dan iklim, dan data sifat fisik tanah. Data sekunder bersumber dari PJT II. Data karakteristik tanah yang dikumpulkan berasal dari data sekunder meliputi sifat fisika tanah yaitu kedalaman efektif, ketebalan horizon, tekstur tanah, bobot isi, kadar air tersedia, konduktifitas hidrolik jenuh, nilai erodibilitas tanah, albedo tanah dan kandungan $\mathrm{C}$ organik. Data iklim yang dikumpulkan yaitu curah hujan harian, suhu udara maksimum dan minimum, kecepatan angin, kelembaban udara dan radiasi matahari.

Penelitian dilakukan melalui 3 tahap yaitu : Tahap pengumpulan data, Tahap analisis dan Tahap penyajian hasil penelitian. Tahap analisis dilakukan dengan bantuan program MapWindow4.6SR dan Micerosoft Excel. Deliniasi daerah penelitian dilakukan menggunakan data DEM $90 \times 90 \mathrm{~m}$ sehingga menghasilkan beberapa sub DAS dimana setiap sub DAS memiliki satu jaringan utama. Proses ini dilakukan dengan treshold $25 \mathrm{~km}^{2}$ sehingga menghasilkan 13 sub DAS. Pembentukan HRU dilakukan berdasarkan karakteristik tanah dan penggunaan lahan yang spesifik dengan cara overlay peta tanah, penggunaan lahan dan lereng. Metode yang digunakan dalam pembentukan HRU adalah treshold by percentage untuk menghasilkan multiple HRU yaitu sebesar 10-10-5 sehingga menghasilkan 299 HRUs. Kemudian dilakukan pembacaan data iklim sehingga simulasi hidrologi untuk daerah tangkapan waduk jatiluhur dapat dilakukan. Analisis hidrologi dilakukan terhadap aliran permukaan, aliran lateral, baseflow, wateryield, dan evapotranspirasi.

Proses kalibrasi model dilakukan dengan dengan cara membandingkan debit hasil perhitungan model dengan debit hasil pengukuran lapang (aktual) tahun 2009 untuk data dari stasiun pengukuru Cisomang. Metode 
statistik yang digunakan untuk tujuan kalibrasi model adalah efisiensi model Nash-Sutcliffe (NS) yang direkomendasikan oleh The American Society of Civil Engineers (Ahl et al. 2008). Setelah proses kalibrasi dilakukan, maka model akan digunakan untuk mensimulasi skenario perubahan iklim yang disusun. Adapun skenario yang dimaksud yaitu:

Skenario 1: peningkatan curah hujan sebesar $10 \%$

Skenario 2: penurunan curah hujan sebesar $15 \%$

Skenario 3: peningkatan suhu sebesar $1^{\circ} \mathrm{C}$

Skenario 4: kombinasi antara peningkatan curah hujan sebesar $10 \%$ dan temperature sebesar $1^{\circ} \mathrm{C}$

\section{HASIL DAN PEMBAHASAN}

Periode simulasi model SWAT untuk daerah tangkapan waduk jatiluhur dilakukan selama 5 tahun mulai dari tahun 2005 hingga 2009 dimana tahun 2005-2008 digunakan sebagai set up model sedangkan tahun 2009 digunakan untuk proses kalibrasi dan kajian. Proses kalibrasi yang dilakukan masih memberikan nilai Nash-Sutcliffe yang rendah yaitu $<0.3$. Hal ini diduga karena kualitas data baik input (terutama data tanah) dan data debit yang digunakan untuk proses kalibrasi memiliki kualitas yang rendah.

Berdasarkan periode kajian yaitu Juni hingga Desember 2009 maka gambaran hidrologi daerah penelitian dapat dilihat pada Tabel 2. Berdasarkan tabel tersebut diketahui bahwa runoff terbesar terjadi pada bulan November tetapi kontribusi terhadap baseflow rendah, jika dibandingkan dengan bulan Desember dimana curah hujannya lebih sedikit dibandingkan November. Hal ini diduga karena pada bulan November dengan curah hujan tinggi, sering terjadi pada waktu yang cepat sehingga air tidak memiliki kesempatan yang lama untuk masuk ke dalam tanah. Dengan demikian curah hujan lebih banyak yang menjadi aliran permukaan dan hanya sebagian kecil saja yang berkontribusi terhadap aliran dasar.
Tabel 2. Karakteristik Hidrologi Daerah Tangkapan Waduk Jatiluhur

\begin{tabular}{|c|c|c|c|c|c|c|}
\hline \multirow{2}{*}{ Bulan } & Curah Hujan & Runoff & Lateral flow & aseflow & aterYielc & biration \\
\hline & \multicolumn{6}{|c|}{-1} \\
\hline 6 & 113.41 & 7.36 & 5.66 & 101.32 & 114.26 & 42.3 \\
\hline 7 & 43.53 & 7.86 & 3.92 & 70.93 & 82.69 & 10.73 \\
\hline 8 & 81.36 & 23.49 & 4.39 & 44.35 & 72.18 & 6.06 \\
\hline 9 & 71.42 & 7.18 & 3.8 & 46.15 & 57.05 & 35.76 \\
\hline 10 & 44.44 & 3.11 & 2.4 & 26.16 & 31.62 & 31.67 \\
\hline 11 & 385.88 & 103.51 & 11.06 & 37.96 & 152.35 & 56.17 \\
\hline 12 & 181.86 & 22.12 & 9.14 & 124.17 & 155.29 & 52.87 \\
\hline Total & 921.9 & 174.63 & 40.37 & 451.04 & 665.44 & 235.56 \\
\hline
\end{tabular}

DAS sebagai suatu ekosistem yang utuh sangat menentukan keberlanjutan seluruh makhluk hidup yang ada di dalamnya. Setiap perubahan yang ada di dalam DAS, termasuk perubahan iklim, secara tidak langsung akan memberikan perubahan pula terhadap semua kegiatan yang dilakukan di dalam DAS, baik kegiatan pertanian, kehutanan, peternakan dan lain sebagainya.

Pada sektor pertanian, perubahan iklim menyebabkan 1) percepatan pematangan dan peningkatan hama penyakit yang akhirnya akan menurunkan hasil (dampak dari peningkatan suhu), 2) fluktuasi ketersediaan air yang tajam dan berpeluang meningkatkan hama penyakit (dampak dari perubahan pola hujan), 3) semakin seringnya banjir dan kekeringan karena peningkatan kejadian iklim ekstrim, 4) pola musim yang tidak jelas sehingga sulit untuk menentukan/mengatur pola tanam, dan 5) kehilangan atau pergeseran lahan pertanian akibat dari peningkatan permukaaan air laut (Runtunuwu dan Amien, 2008). Masalahmasalah tersebut apabila tidak ditangani dengan serius pada akhirnya dapat mengganggu ketahanan pangan nasional.

Berdasarkan hal tersebut, maka dalam kajian ini dilakukan simulasi terhadap perubahan iklim yang mengacu pada nilai-nilai hasil penelitian terdahulu baik IPCC maupun sejumlah peneliti lainnya. Hasil simulasi dari 4 skenario yang disusun terutama akan dikaji terkait dengan perubahan aliran permukaan, wateryield dan evapotrasnpirasi. Hasil simulasi tiap scenario terhadap aliran permukaan, wateryield dan evapotranspirasi disajikan pada Tabel 3, Tabel 4 dan Tabel 5. 
Tabel 3. Hasil Simulasi Skenario Perubahan Iklim terhadap Aliran Permukaan

\begin{tabular}{|crrrrr}
\hline \multirow{2}{*}{ Bulan } & \multicolumn{5}{c}{ Runoff $(\mathrm{mm})$} \\
\cline { 2 - 6 } & Eksisting & S1 & S2 & S3 & S4 \\
\hline 6 & 7.36 & 10 & 4.18 & 7.42 & 10.06 \\
\hline 7 & 7.86 & 9.93 & 5.11 & 7.98 & 10.07 \\
\hline 8 & 23.49 & 28.6 & 16.44 & 23.46 & 28.57 \\
\hline 9 & 7.18 & 9.54 & 4.26 & 7.05 & 9.38 \\
\hline 10 & 3.11 & 4.39 & 1.6 & 3.03 & 4.29 \\
\hline 11 & 103.51 & 125.54 & 73.33 & 103.23 & 125.21 \\
\hline 12 & 22.12 & 28.64 & 13.85 & 22.03 & 28.55 \\
\hline Total & 174.63 & 216.64 & 118.77 & 174.2 & 216.13 \\
\hline
\end{tabular}

Tabel 4. Hasil Simulasi Skenario Perubahan Iklim terhadap Wateryield

\begin{tabular}{|rrrr|r|r}
\hline \multirow{2}{*}{ Bulan } & \multicolumn{5}{c}{ Water Yield (mm) } \\
\cline { 2 - 6 } & Eksisting & \multicolumn{2}{c}{ S1 } & \multicolumn{3}{c}{ S3 } & \multicolumn{2}{c}{ S4 } \\
\hline 6 & 114.26 & 124.17 & 99.11 & 113.58 & 123.51 \\
\hline 7 & 82.69 & 92.07 & 68.12 & 84.09 & 93.48 \\
\hline 8 & 72.18 & 81.58 & 57.94 & 72.81 & 82.35 \\
\hline 9 & 57.05 & 63.45 & 47.37 & 56.12 & 62.58 \\
\hline 10 & 31.62 & 37.85 & 21.71 & 29.3 & 35.56 \\
\hline 11 & 152.35 & 179.25 & 114.2 & 151.46 & 178.28 \\
\hline 12 & 155.29 & 173.26 & 128.09 & 154.16 & 172.13 \\
\hline Total & 665.44 & 751.63 & 536.54 & 661.52 & 747.89 \\
\hline
\end{tabular}

Tabel 5. Hasil Simulasi Skenario Perubahan Iklim terhadap Evapotranspirasi

\begin{tabular}{|rrrrrrr}
\hline \multirow{2}{*}{ Bulan } & \multicolumn{5}{c}{ Evapotranspiration (mm) } \\
\cline { 2 - 6 } & Eksisting & S1 & \multicolumn{2}{c}{ S2 } & \multicolumn{2}{c}{ S3 } \\
\hline 6 & 42.3 & 42.36 & 42.14 & 40.32 & 40.37 \\
\hline 7 & 10.73 & 10.75 & 10.67 & 9.27 & 9.28 \\
\hline 8 & 6.06 & 6.06 & 6.06 & 7.47 & 7.47 \\
\hline 9 & 35.76 & 35.79 & 35.69 & 37.55 & 37.6 \\
\hline 10 & 31.67 & 31.86 & 31.25 & 32.28 & 32.5 \\
\hline 11 & 56.17 & 56.24 & 56.06 & 57.52 & 57.62 \\
\hline 12 & 52.87 & 52.93 & 52.61 & 54.02 & 54.11 \\
\hline Total & 235.56 & 235.99 & 234.48 & 238.43 & 238.95 \\
\hline
\end{tabular}

Berdasarkan Tabel 3. diketahui bahwa skenario peningkatan curah hujan sebesar $10 \%$ (S1) akan meningkatkan nilai aliran permukaan sebesar 21.28-41.16\% sedangkan skenario penurunan curah hujan sebesar $15 \%$ (S2) menurunkan aliran permukaan sebesar 29.16$48.55 \%$. Skenario 3 (peningkatan temperatur sebesar $1^{\circ} \mathrm{C}$ memberikan pengaruh yang bervariasi terhadap aliran permukaan dimana nilai aliran permukaan meningkat sebesar 0.82 $1.53 \%$ dan pada akhir periode simulasi mengalami penurunan sebesar $0.13-2.57 \%$. Skenario keempat (yaitu kombinasi antara peningkatan curah hujan sebesar $10 \%$ dan temperature sebesar $1^{\circ} \mathrm{C}$ meningkatkan aliran permukaan sebesar 20.96-37.94\%. Peningkatan persentase aliran permukaan pada skenario 4 sedikit lebih rendah dibandingkan skenario 1 karena adanya kombinasi dengan peningkatan temperatur sebesar $1^{\circ} \mathrm{C}$. secara keseluruhan untuk semua periode simulasi Juni-Desember 2009, peningkatan curah hujan sebesar $10 \%$ dan suhu udara sebesar $1^{\circ} \mathrm{C}$ akan meningkatkan aliran permukaan sebesar 23.76\%. Hasil simulasi perubahan iklim (Hailemariam, 1999 dalam WWF Indonesia, 2007) untuk DAS Citarum menunjukkan bahwa peningkatan curah hujan sebesar $10 \%$ dan suhu udara sebesar $2-4^{\circ} \mathrm{C}$ akan meningkatkan runoff tahunan sebesar 4 hingga 12\%. Peningkatan suhu udara menyebabkan sebagian dari curah hujan memberikan kontribusi yang lebih terhadap evapotranspirasi sehingga aliran permukaan menjadi rendah. Adapun peningkatan evapotranspirasi sebagai akibat dari meningkatnya suhu sebesar $1^{\circ} \mathrm{C}$ berkisar antara 1.93-23.27\% (Tabel 5).

Pengaruh berbagai skenario terhadap wateryield pun bervariasi. Skenario 1 meningkatkan wateryield sebesar $8.67-19.70 \%$ dan skenario 4 meningkatkan wateryield sebesar $8.10-17.02 \%$. Sedangkan skenario penurunan curah hujan sebesar $15 \%$ dan peningkatan suhu sebesar $1^{\circ} \mathrm{C}$ masing-masing menurunkan wateryield sebesar $13.26-31.34 \%$ dan $0.58-7.34 \%$. Peningkatan wateryield disatu sisi akan memberikan keuntungan kepada masyarakat sekitar apabila dapat disimpan di dalam tanah sehingga pada saat musim kemarau masih tersedia air. Tetapi apabila peningkatan wateryield tersebut tidak dapat dikelola dengan baik maka akan memberikan dampak negative seperti banjir. Penurunan wateryield akan memberikan dampak negatif bagi masyarakat sekitar terutama petani karena mereka akan kekurangan air untuk kegiatan pertanian. Oleh karena itu diperlukan adanya suatu upaya untuk mengurangi atau mencegah terjadinya kerusakan di daerah tangkapan waduk Jatiluhur. Hal ini tentu saja sangat membutuhkan dukungan dari banyak pihak yang terlibat dalam pengelolaan daerah tangkapan waduk jatiluhur, terutama stakeholder lokal. Dengan demikian diharapkan bahwa kerusakan yang mungkin saja terjadi karena perubahan iklim dapat diminimalisir.

\section{KESIMPULAN}

a. Perubahan iklim mempengaruhi karakteristik hidrologi suatu DAS. Peningkatan curah hujan sebesar $10 \%$ 
akan meningkatkan nilai aliran permukaan sebesar 21.28-41.16\% sedangkan penurunan curah hujan sebesar $15 \%$ menurunkan aliran permukaan sebesar 29.16-48.55\%.

b. Peningkatan curah hujan sebesar $10 \%$ dan temperatur sebesar $1^{\circ} \mathrm{C}$ meningkatkan aliran permukaan sebesar 20.96-37.94\%.

c. Perlu adanya suatu usaha untuk adaptasi terhadap perubahan iklim yang terjadi sehingga kerusakan dapat diminimalisir.

\section{DAFTAR PUSTAKA}

Ahl, R. S., S. W. Woods and H. R. Zuuring. 2008. Hydrologic Calibration and Validation of SWAT in A SnowDominated Rocky Mountain Watershed, Montana, USA. Journal of The American Water Resources Association; Dec 2008; 44, 6; Proquest Agriculture Journals pg 1411.

Guo, H., Q. Hu, and T. Jiang. 2008. Annual and Seasonal Streamflow Responses to Climate and Land Cover Changes in the Poyang Lake Basin, China. Journal of Hydrology (2008), 355:106-122.

IPCC. 2007. Summary for Climate Change: The Physical Science Basis. Cambridge University Press. New York

Neitsch, S. L., J. G. Arnold, J. R. Kiniry and J. R. Williams. 2001. 2005. Soil and Water Assessment Tool: Theoretical Documentation Version 2005. Agricultural Research Service and Texas Agricultural Experiment Station.

Potyondy, J. P., and T. W. Geier. 2011. Watershed Condition Classification Technical Guide. Forest Service, United States Department of Agriculture.

Runtunuwu, E., dan I. Amien. 2008. Dampak dan Antisipasi Perubahan Iklim Sektor Pertanian. Prosiding Identifikasi Dampak Perubahan Iklim pada Sumberdaya Air di Indonesia. ISBN: 978-979-8801-36-5.

WWF Indonesia. 2007. Climate Change Impacts on the Management of Citarum Watershed. WP 91, Cifor. Bogor.

Yuwono, A. 2013. Pengelolaan DAS Citarum dalam Perspektif Perubahan Iklim. www.klh.or.id (1 April 2013). 